\title{
THE OSTRACON FROM THE DAYS OF DAVID FOUND AT KHIRBET QEIYAFA
}

\author{
Alan Millard
}

\begin{abstract}
Summary
A newly discovered ostracon at Khirbet Qeiyafa which dates from about $1000 \mathrm{BC}$ is a welcome addition to the meagre examples of writing which survive from that period. The letters are difficult to read and the language may be Hebrew, Canaanite, Phoenician or Moabite. Translations range from a list of names to commands concerning social justice. The simplest explanation is that this is a list of Hebrew and Canaanite names written by someone unused to writing. They help to suggest that writing was practised by non-scribes, so the skill may have been widespread.
\end{abstract}

\section{Introduction}

Discoveries of written documents in the Holy Land are always noteworthy, especially those from the Eleventh and Tenth Centuries BC. From those centuries there are very few examples indeed. There are only two of any length. The Gezer Calendar is well known, found during the Palestine Exploration Fund's work at the site in 1908, and generally dated to about $925 \mathrm{BC}$. A more recent find is the alphabet scratched on a boulder unearthed at Tel Zayit by the Pittsburgh Theological Seminary expedition in 2005. ${ }^{1}$ Apart from these there are only personal names scratched on a stone and on potsherds that can be placed approximately in the Tenth Century, the period of the reigns of David and Solomon. They are part of a gaming board from Beth

1 R. E. Tappy, P. K. McCarter, ed., Literate Culture and Tenth Century Canaan: The Tel Zayit Abecedary in Context (Winona Lake: Eisenbrauns, 2008). 
Shemesh, ${ }^{2}$ and sherds from Tell eș-Șafī (probably Gath), ${ }^{3}$ from Tel 'Āmal, near Beth-Shan, from Timnah, and from Khirbet Rosh Zayit, near Kabul in the north, which might be Phoenician. ${ }^{4}$ Earlier than that, there are equally few documents assigned to the Eleventh and Twelfth Centuries: little more than names on potsherds from Khirbet Raddana, Lachish, Manahat and Qubur el-Walayda, the 'Izbet Șarțah ostracon bearing several lines faintly scratched, one legible as an abc, a hardly legible ink-written ostracon from Beth Shemesh, names incised on bronze arrowheads and a name incised on a bronze bowl found at Kefar Veradim in the north, which may be Phoenician. ${ }^{5}$

The scarcity of inscriptions from the Holy Land in the Twelfth to Tenth Centuries $\mathrm{BC}$ and the relative rarity of Hebrew epigraphic remains from the Ninth Century when compared with the Eighth to Sixth Centuries continues to arouse discussion. ${ }^{6}$ According to a widely held hypothesis, the absence of a central administration is the reason: with no unifying power there would be nothing to employ scribes. The few documents from the Twelfth to Tenth Centuries have otherwise been explained as products of scribes working for an élite class, 'writing was a small-scale luxury craft'. ${ }^{7}$ Yet we may ask: Could only the élite afford to pay a scribe to write a name or a dedication on a pot? Who were those élite? Would a family like Elkanah's qualify? He was able to afford gifts of a bullock, flour and wine for the shrine at Shiloh (1 Sam. 1:24). Ryan Byrne, who expressed this view, even sees how rare scribes were in the naming of a single scribe in each of the two lists of David's entourage, Seraiah and Sheva: 'David retains a scribe

2 S. Bunimovitz and Z. Lederman, 'Culture Conflict on Judah's Frontier,' Biblical Archaeology Review 23.1 (1997): 42-49, 75-77.

3 A. M. Maeir, S. J. Wimmer, A. Zukerman and A. Demsky, 'A Late Iron Age I/Early Iron Age II Old Canaanite Inscription from Tell eș-Ṣafī/Gath, Israel: Palaeography, Dating, and Historical-Cultural Significance', BASOR 351 (2008): 1-33; colour photograph in Biblical Archaeology Review (March-April 2006): 16.

4 J. Renz \& W. Röllig, Handbuch der althebräischen Epigraphik, I (Darmstadt: Wissenschaftliche Buchgesellschaft, 1995): 29-30, 37-38.

5 For these texts see the refernces in P. K. McCarter, 'Paleographic Notes on the Tel Zayit Abecedary', in R. E. Tappy, P. K. McCarter, ed., Literate Culture and Tenth Century Canaan, 45-59; Y. Alexandre, 'A Canaanite-Early Phoenician Inscribed Bronze Bowl in an Iron Age II A-B Burial Cave at Kefar Veradim, Northern Israel', Maarav 13 (2006): 7-41.

6 The difference is displayed by the lists given in J. Renz \& W. Röllig, Handbuch der althebräischen Epigraphik, I, 11-19.

7 So expressed by S. Sanders, 'Writing and Early Iron Age Israel: Before National Scripts, Beyond Nations and States', in R. E. Tappy and P. Kyle McCarter, ed., Literate Culture and Tenth-Century Canaan, 97-112, see 106. 
when scribes are curiosities' ${ }^{8}$ failing to observe that a single scribe, Shebna, is named among Hezekiah's officials who faced the Assyrian generals (2 Kgs 18:18), in a period when scribes are universally admitted to have been more numerous and active. (Jonathan, an uncle of David is named as a scribe in 1 Chronicles 27:32, a notice which, unless fictional, has the appearance of veracity, cf. 2 Sam. 8; 16; 1 Chron. 18: 15.) Seth Sanders has taken a slightly different approach: that 'scribalism ... was not what was being created by a state ... but what the state was coopting for its own purposes'.?

These explanations fail to recognise adequately that alphabetic writing was already established in Canaan in the Late Bronze Age and continued into the Iron Age. It did not disappear and have to be reintroduced or invented afresh, as was the case in Greece with Linear B and the alphabet. Israel and the neighbouring kingdoms inherited the Canaanite Linear Alphabet with other elements of material culture when they arose in the region. Certainly there was influence from the Phoenician, née Canaanite, centres on the coast, Byblos, Sidon, Tyre; regrettably, only Byblos has yielded inscriptions early enough for comparison. The restriction of the number of letters to twenty-two (or twenty-one) had already taken place by the end of the Late Bronze Age, as the examples of the shorter cuneiform alphabet demonstrate, found scattered from Ugarit to Ta'anach and Mount Tabor. The similarity between the letter forms at Byblos and those of the Gezer Calendar and the Tel Zayit abecedary have led to the assumption of a close relationship, but we should note that no texts of the Twelfth to Tenth Centuries have been found at coastal sites south of Byblos which might reveal other centres of scribal activity.

The newly found ostracon is very welcome, therefore, as it adds a significant element to this meagre epigraphic harvest. The site of Khirbet Qeiyafa is a hill-top on the north side of the valley of Elah, between Azekah and Socoh. ${ }^{10} 1$ Samuel 17 reports the Philistine army faced the Israelites in the valley and David slew Goliath there. The site passed almost unremarked until abundant Iron Age IIA potsherds were noticed. Excavations in 2008 discovered that there had been a

8 R. Byrne, 'The Refuge of Scribalism in Iron I Palestine', BASOR 345 (2007): 1-31.

9 Sanders, 'Writing and Early Iron Age Israel', 107.

10 Y. Garfinkel and S. Ganor, Khirbet Qeiyafa Vol. 1: Excavation Report 2007-2008 (Jerusalem: Israel Exploration Society: Institute of Archaeology, Hebrew University of Jer., 2009). I am grateful to Graham Davies for making a copy of this available to me. 
Hellenistic occupation on top of the Iron Age IIA remains and nothing in between. So Yossi Garfinkel and Saar Ganor decided to explore the site in the hope of clarifying some of the problems and debate surrounding the period of and questions about the United Monarchy which Israel Finkelstein and others have opened.

In the surrounding wall there are two types of stonework which were shown to belong to the two periods: the small stones at the top were Hellenistic additions to the boulders of the earlier wall. A fourchamber gateway, clearly belonging to the earlier period, was found on the west side, inserted where a space had been designed for it as the wall was built. Another gate, on the south side, opened on to the slope of the Elah valley. The presence of two gateways is unusual and suggested to Anson Rainey that the place is the Sha arayim (Two Gates) of 1 Samuel 17:34; other identifications have also been proposed. Inside, the wall turns out to be a casemate construction, with each of the chambers serving as the back room of a house. The large quantities of pottery found in each house cleared all belong to Iron Age IIA, or, perhaps, late Iron Age I, ${ }^{11}$ and that, with Carbon 14 samples, enables the use of the site to be set in the decades either side of 1000 BC. Apparently it was only used for a short period. Who the builders and inhabitants were remains uncertain. Examples of 'Ashdod ware', in the Philistine tradition need not indicate Philistine occupation. The careful construction of the wall and gates indicates a measure of control and experience in erecting defences.

It was in a room adjacent to a casemate in Building 2, north of the west gate, that the ostracon lay. Before considering what it may say, there are some observations to make. The sherd from a large jar is about 6 inches square (maximum dimensions $15 \times 16.5 \mathrm{cms}$ ) and bears a text written in black ink much longer than any other alphabetic inscription of this date. There could be several lines of text missing before the first line and possibly some letters at the right edge. The inconsistent ways the letters are written indicates that this is not the work of an experienced scribe. Indeed, it is not quite certain whether each line is to be read from left to right or from top to bottom. Whether it was written at the site where it was found or brought from another place, we cannot know.

11 According to L. Singer-Avitz, 'The Relative Chronology of Khirbet Qeiyafa', Tel Aviv 37.1 (2010): 79-83. 
The Israeli scholar who published the ostracon, Haggai Misgav, only ventured to read some letters, as did Aaron Demsky, Shmuel Ahituv and the experienced palaeographer Ada Yardeni. Since the primary publication, Gershon Galil of Haifa University and Émile Puech of the École Biblique have each made their own drawings and proposed almost complete readings of this text. ${ }^{12}$ If they are correct, their interpretations affect understanding of social justice at the time.

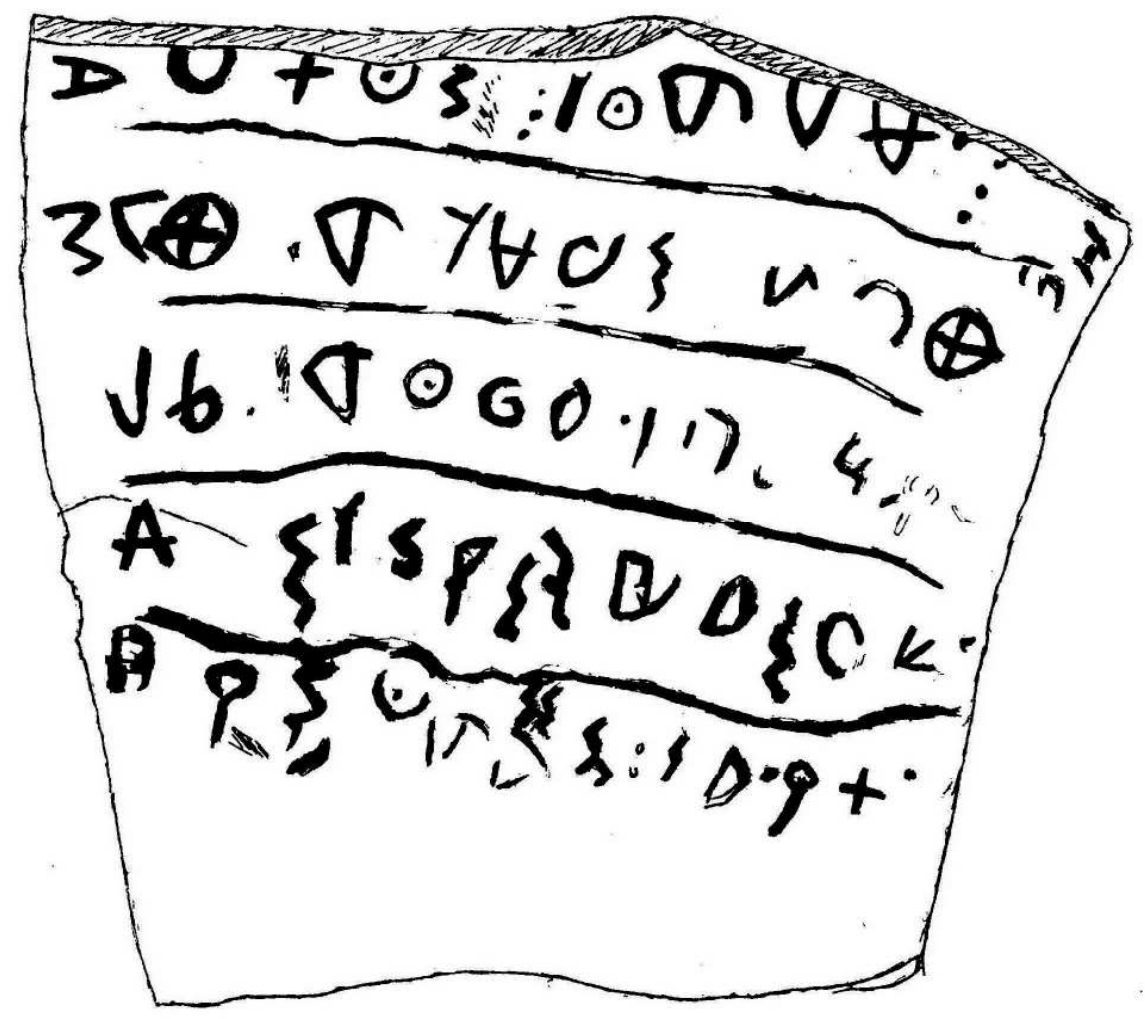

Drawing of the ostracon, by H. Misgav (from Y. Garfinkel and S. Ganor, Khirbet Qeiyafa Vol. 1. Excavation Report 2007-2008 (Jerusalem: Israel Exploration Society, 2009): 245).

12 I am grateful to G. Galil for discussing with me his interpretation which has been published as, 'The Hebrew Inscription from Khirbet Qeiyafa/Neta'im: Script, Language, Literature and History', in Ugarit Forschungen 41 (2009): 193-242; E. Puech, 'L'ostracon de Khirbet Qeyafa et les débuts de la royauté en Israël', $R B 117$ (2010): 162-84. 
In translating any ancient text, especially one that is unique in various ways, some caution is essential. An eminent British Assyriologist in the last century used to say, 'If your translation is nonsense, it is certainly wrong; if it makes sense, it may well be wrong, but just possibly might be right!' Since the photographs of the potsherd were published, some specialists in ancient Hebrew epigraphy have commented on it, and their observations deserve to be heard with respect. What are the interpretations offered?

1. Haggai Misgav, 'The reading of the first line supports the identification of the text as Hebrew', 'the verbs identified in the first line are Hebrew' and the text 'is phrased as a message from one person to another'. 'The inscription begins with several words of command which may be judicial or ethical in content... The end of the inscription contains words which may relate to the area of politics or government. It is difficult to extract more meaning from this text at the present stage. We can determine, however, that the text has continuity of meaning, and is not merely a list of unconnected words.' ${ }^{13}$

2. Ada Yardeni thought the text could be 'perhaps Hebrew' and, while she did not think it likely to be a list of names, did not rule out that possibility. ${ }^{14}$

3. Aaron Demsky saw it as a scribal exercise, a list of words which the student was required to learn.

4. Shmuel Ahituv also took it to be a practice text of some sort. ${ }^{15}$

5. Gershon Galil carries Misgav's suggestion a long way forward, believing the text is 'a social statement relating to slaves, widows and orphans'. His translation is:

1) do not do [it], but worship [...].

2) Judge the slave and the widow / Judge the orph[an]

3 ) and the stranger. Plead for the infant / plead for the poor and

4) the widow. Avenge (the pauper's vengeance) at the king's hands

5) Protect the poor [and] the slave / su[pport] the stranger.'

13 H. Misgav, 'The Ostracon' in Khirbet Qeiyafa Vol. 1, ed. Garfinkel: 255, 256.

14 A. Yardeni in 'The Ostracon' in Garfinkel, Khirbet Qeiyafa 1, 259, 260.

15 The opinions of A. Demsky and S. Ahituv were reported in D. Amit et al., Proceedings of a Conference on New Discoveries in the Archaeology of Jerusalem and Its Surroundings Held at the Hebrew University, 15th October, 2009 [in Hebrew], 126-29 and 130-32. The text was kindly sent to me by A. Demsky. 
6. Émile Puech offers:

'... Toi, (le/ton) compatriote/necessiteux(?)]

1) n'opprime pas, et sers $\mathrm{Di}[\mathrm{eu}]$ : 1: Le/a spoliait

2) le juge et la veuve pleurait; il avait pouvoir

3) sur l'étranger résidant et sur l'enfant, et les supprimait ensemble.

4) Les hommes et les chefs/officiers ont établi un roi.

5) Il a marqué <soixante> serviteurs parmi les communautés/habitations/ générations.'

Now it is quite likely that an ostracon could contain a message, as a draft, an original, or the record of an oral delivery; from Judah in the Seventh Century BC the Lachish Letters, the Mesad Hashavyahu Letter and others illustrate that. Equally, ostraca may contain lists of names or be writing exercises.

In reading a unique ancient text, all alternative possibilities for understanding it should be explored. Often the simplest, the most banal interpretation is the preferable one. A good example of that principle is the treatment of one of the Dead Sea Scroll fragments. Two scholars published the fragment $4 \mathrm{Q} 341$ as a medical text, but another, the expert epigraphist Joseph Naveh, showed clearly that it is only a writing exercise, using biblical proper names and letters of the alphabet, and all competent to judge now accept that, although it has been suggested there was a magical purpose behind it. ${ }^{16}$

The problem with this ostracon is that some letters are partly obliterated, that the same letter may have more than one stance or shape and that some are not certainly identified. According to G. Galil, the same letter occurs in two forms side by side $-l$ in line 3, numbers 7 and 8 , and $r$ in line 4, numbers 3 and 4, and also inverted as number 9 . However, the different stances a single letter takes would probably not make it unrecognisable to a reader. On the basis of previous discoveries, the script is not what would be expected at about 1000 BC; it is 'Canaanite' rather than Phoenician or Hebrew, and some of the forms are unparalleled. The appearance of a word divider in the form of three dots in a vertical line in line 1 only, as well as the varied stances and the uneven rulings between the lines may imply haste. Any

16 J. Naveh, 'A Medical Document or a Writing Exercise? The So-Called 4Q Therapeia', IEJ 36 (1986): 52-55; G. J. Brooke, '4Q31: An Exercise for Spelling and for Spells?' in Writing and Ancient Near Eastern Society: Papers in Honour of Alan R. Millard, ed. P. Bienkowski, C. B. Mee and E. A. Slater (London: T\&T Clark [2005]): 271-82. 
reading, therefore, has to be treated as provisional; no weighty conclusions should be drawn from any single interpretation.

\section{Khirbet Qeiyafa ostracon line 1}

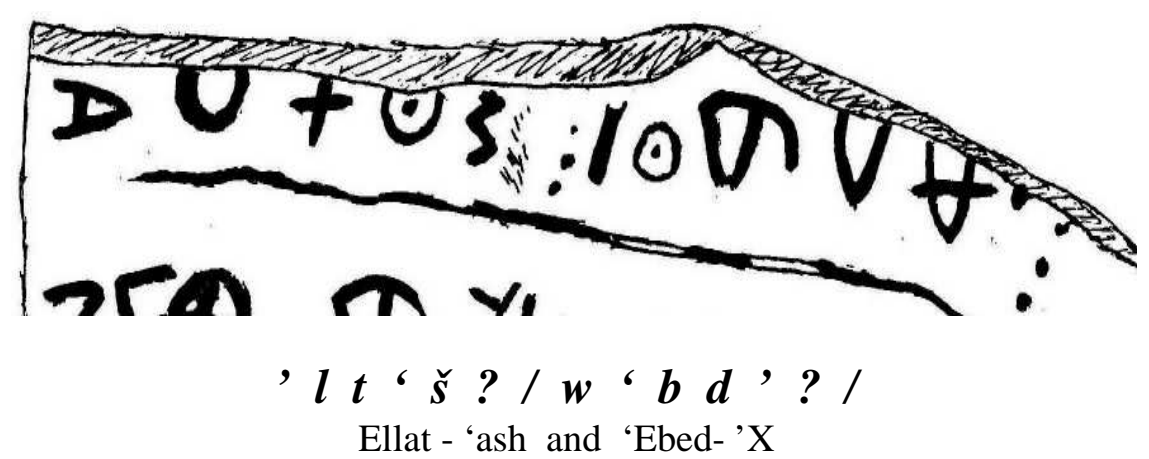

Both the presentation by Gershon Galil and by Émile Puech, involve uncertain or restored letters in each line, some rather smaller than others, which raises the level of uncertainty. In the first line Galil has adopted a particular translation of the second word, w'bd as 'but worship', when the verb equally well means 'but work, serve'. Accepting the first word as 'Do not do (it)', this second one could be 'but make'. That would alter the tenor of the first line, at least, removing the religious note.

It is the reading of the first five letters which has tended to impose the understanding of the text as Hebrew and as an instruction from a superior. Reading the first five letters as a negative command 'al ta 'aś 'do not do, make,' immediately suggests the language as Hebrew because the verb 'sh is well known only in Hebrew (and Moabite), although it may occur in the Thirteenth Century BC in Ugaritic. Yet before accepting that identification, we should check for alternatives, not because we do not want the text to be Hebrew, but in order to avoid precluding other possibilities and so, perhaps, prescribe the translation to some extent. Ed Cook has observed that the first five letters could be read as a personal name, Ellat-'aš, 'the goddess (or Ellat) helped'. ${ }^{17}$ The verbal element ' $a \check{s}$, occurs in Hebrew names,

17 See his 'blog' 'Ralph the Sacred River', 14 March 2010. I am indebted to him for permitting me to adopt his insights. 
Ye 'ush (1 Chron. 7:10, etc.) and Yo'ash (1 Chron. 7:8), and in names in other Semitic languages. ${ }^{18}$ The word for 'goddess' has been identified in the inscription on the Late Bronze Age (Canaanite) jug found at Lachish. If the first word is a personal name, then the second, $w^{\prime} b d[$ ] could well be another, 'and Ebed-X'. Taking the trace after aleph as a lamedh, Puech reads w'bd'l, 'and serve God, but, again, these letters could spell the personal name 'Abd-'el or 'Abdi-'el (Jer. 36:26; 1 Chron. 5:15).

\section{Khirbet Qeiyafa ostracon line 2}

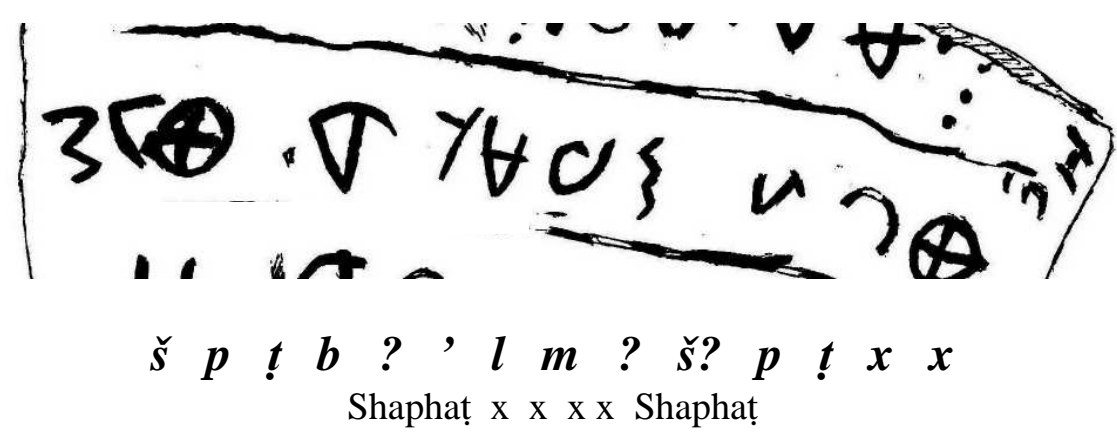

In the second line the first word is clearly $\check{s} p t$, the word for 'judge' or 'he judged', but equally well Shaphat, another name known from the Bible. That is followed by $b$, then an unclear sign (Yardeni and Galil read a $w$ ), ' $l m$ with another abraded sign (not drawn by Misgav) which Galil and Puech believe is $n$, allowing them to read the noun 'Imn 'widow'. There may be another Shaphat at the end of the line, then traces of letters starting with $y$ curving around the end of the first line, perhaps forming the second element of the name.

18 Amorite, S. Arabian, H. B. Huffmon, Amorite Personal Names in the Mari Texts (Baltimore, MD: Johns Hopkins University Press, 1965): 171; cf. N. Avigad and B. Sass, Corpus of West Semitic Stamp Seals (Jerusalem: Israel Academy, 1997): 521. 


\section{Khirbet Qeiyafa ostracon line 3}

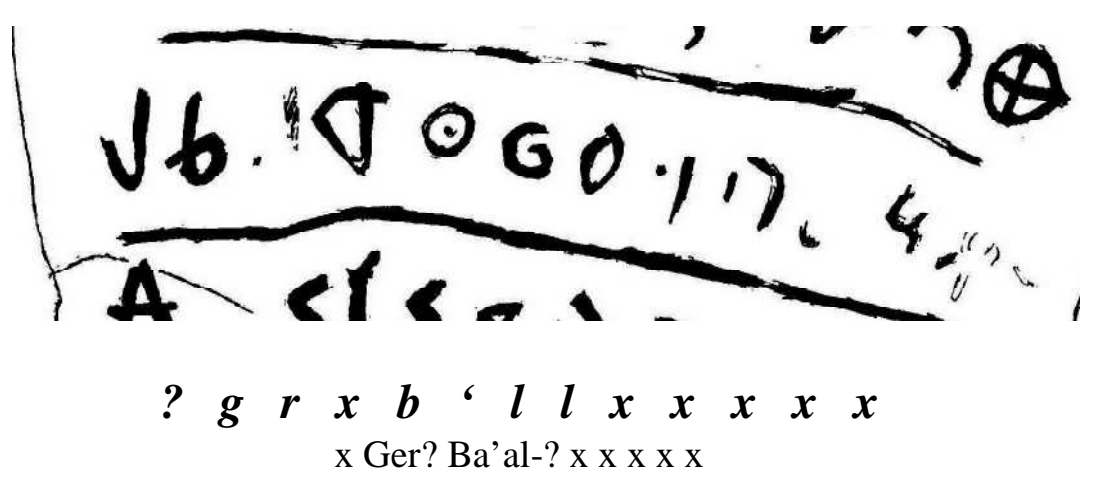

The opening of the third line is unclear. Although Haggai Misgav's drawing shows nothing, there is a blur in the photographs which may be a letter, Gershon Galil reading a $w$ and Ada Yardeni hesitatingly and Émile Puech more certainly a $b$. Then Yardeni, Galil and Puech read a $g$ and an $r$ but the next letter is doubtful. There are names beginning $g r$ in the Bible, such as Gera and Gareb. After that the letters $b$ ' $l l$ are accepted, which could be part of a name Ba'al-X, although for Galil and Puech ' $l l$ spell the word for 'child'.

\section{Khirbet Qeiyafa ostracon line 4}

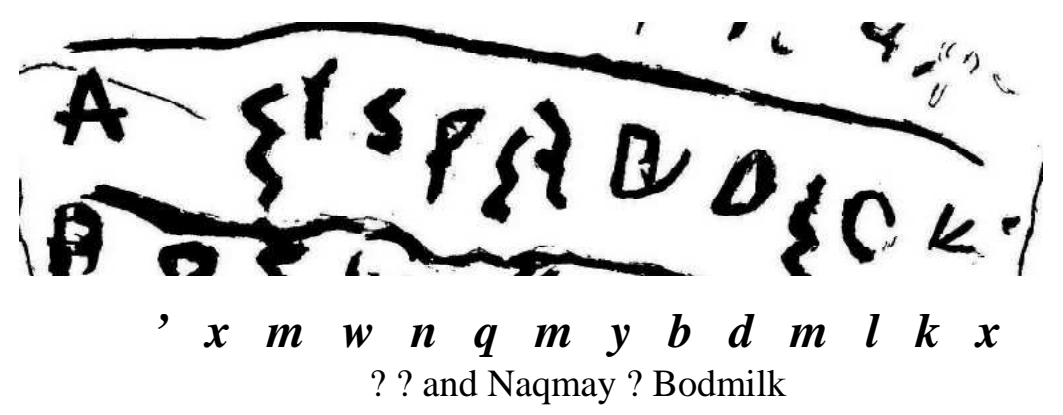

Only some of the letters in the first half of line 4 are clear, but $n q m$ are recognisable in the middle, which can be the word 'vengeance' used in names from the Second Millennium BC onwards in Phoenician 
and elsewhere, ${ }^{19}$ yet not in biblical Hebrew, although apparently incised on a potsherd from Jerusalem. ${ }^{20}$ At the end of the line the letters $b d m l k$ can be the personal name Bodmilk, "by the hand of the King' attested in Phoenician. ${ }^{21}$

\section{Khirbet Qeiyafa ostracon line 5}

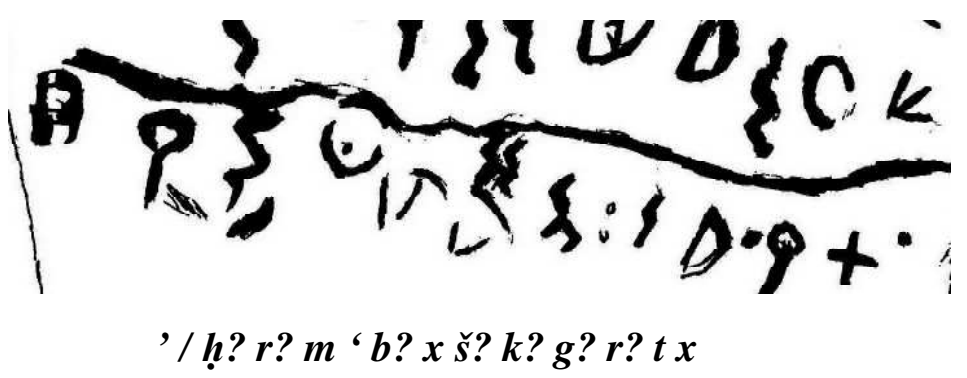

The fifth line is obscure; if the final letters are grtx they could be part of a name. In the middle there may be an erasure or overwriting. Ada Yardeni and Émile Puech read the first three letters as $h r m$, but Gershon Galil sees 'byn, 'poor'-a good example of the problems facing anyone who tries to decipher this ostracon!

If this is a list of names, then they are not distinctively Hebrew, in fact, if Bodmilk is right, they should be more closely linked to Phoenician, which is a form of Canaanite, so the names might simply be Canaanite, or they might be a mixture of Canaanite and Hebrew. An example of a list of names of mixed origin is an ostracon from Nimrud which has names considered to be Ammonite, but some could equally well be Hebrew. ${ }^{22}$

This interpretation is not original to me; Ed Cook, who read the opening letters as a personal name, offered most of it in March 2010 (see n. 17). As I prefer the simplest interpretation of any ancient document, this seems the most attractive reading and so the Khirbet Qeiyafa ostracon can be treated as a list of personal names. As a list of

19 For references, see R. Hess, Amarna Personal Names (ASOR Dissertation Series 9; Winona Lake: Eisenbrauns, 1993): 209.

20 J. Prignaud, 'Notes d'épigraphie hébraïque,' $R B 77$ (1970): 50-59.

21 F. L. Benz, Personal Names in the Phoenician and Punic Inscriptions (Studia Pohl 8; Rome: Biblical Institute Press, 1972): 283-85.

22 K. P. Jackson, The Ammonite Language of the Iron Age (Harvard Semitic monographs 27; Chico, CA: Scholars Press, 1983): 63-67. 
names, written by a pupil scribe or someone unused to writing, maybe working in a hurry, we may compare this with the list of names of the seventy-seven leaders at Sukkoth which a young man wrote for Gideon (Judges 8:14). Of course, other explanations can be considered, but only a really convincing one, based on assured readings, should be accepted. If further examination supports the readings of Haggai Misgav, or of Ada Yardeni, of Gershon Galil or of Émile Puech as a series of connected sentences, then they will tell something about the society of the time and its expectations, but with no clear connection to Jerusalem or its rulers.

The Khirbet Qeiyafa ostracon reveals nothing directly about the kingdom of David and Solomon! Since there is no proof the text is written in Hebrew rather than Canaanite, we cannot say it is an Israelite product. Indeed, the fortified hill-top, standing as it does on the north side of the valley of Elah, on the frontier between Israel and Philistia, could have been in Canaanite, Israelite, or Philistine hands when the ostracon was written.

What the Khirbet Qeiyafa ostracon does show is the existence of one or more writers and therefore readers in the area at about $1000 \mathrm{BC}$. The awkward writing suggests, as others have observed, the work of a learner, which means there was a teacher. The difference between the shapes of the letters on the ostracon and those in the other, rare, alphabetic documents of the Twelfth to Tenth Centuries, may point to a local, individual teacher, perhaps isolated from the mainstream, rather than a centrally organised clerical system, such as prevailed from the Ninth Century onwards. If the surviving examples of writing from this time are held to represent the range of documents created, then we may say, with Seth Sanders, that 'we can never safely assume the existence of a genre or use for writing without concrete evidence'. ${ }^{23}$ Yet we have to remember that the examples of writing available are so meagre and mostly brief, making any sweeping conclusions dangerous and so prefer to assume there was much that is not visible. David Carr illustrated the point: 'If we did not have the Hebrew Bible and were limited to the kind of inscriptional evidence for Israel that we have for Phoenicia, the only literary texts to which we would have access would be fragments, such as the Keteph Hinnom

23 S. Sanders, The Invention of Hebrew (Urbana: University of Illinois Press, 2009): 105. 
amulets and the (still unpublished) hymnic inscription from Kuntillet 'Ajrud. On this basis, we might (wrongly) conclude from silence that, essentially, Israel lacked any sophisticated literature.'24

Writing in the Canaanite Linear Alphabet continued from the Late Bronze Age into the Early Iron Age when all other writing systems had disappeared from the Holy Land. The stray pieces that survive are only visible to us because they are on durable surfaces. Most writing was done on papyrus, leather, or wax-covered wooden boards and has perished. Moreover, most of the physical relics at any site belong to the final phase of any period of occupation, so places with long histories will yield less from the early phases of each period and if there was a gradual, peaceful transition from one period to the next, most of the remnants from earlier eras will have been discarded. ${ }^{25}$ Consequently, any expectation of finding archives from the Tenth or Ninth Centuries BC will almost certainly be disappointed. The Samaria Ostraca survived as rubbish; otherwise the destructions by Sargon, Sennacherib and Nebuchadnezzar are the events which have allowed the recovery of most Hebrew ostraca and bullae. Despite the negative attitudes some people take, I see no good reason to doubt the existence of a kingdom ruled by David from Jerusalem and happily associate the Khirbet Qeiyafa ostracon with that time, without supposing it tells us more than that someone wrote something in a local language on a potsherd in a small town in the countryside, or sent it to one. If someone could do that, there is good reason to believe others could write more and more extensively on perishable surfaces in larger places, even in Jerusalem.

24 D. M. Carr, 'The Tel Zayit Abecedary in Social context' in Literate Culture, ed. R. E. Tappy and P. Kyle McCarter, 113-29.

25 See my essay 'Only Fragments from the Past: The Role of Accident in our Knowledge of the Ancient Near East' in Writing and Ancient Near Eastern Society, ed. P. Bienkowski, C. B. Mee and E. A. Slater, 301-319. 